\title{
El heroísmo en los tiempos actuales: Antigona furiosa de Griselda Gambaro y Usted está aqui de Bárbara Colio
}

\section{Heroism today: Griselda Gambaro's Antígona furiosa and Bárbara Colio’s Usted está aquí}

Claudia Gidi Blanchet Universidad Veracruzana

Resumen

Los mitos dicen tanto de la condición humana que se cuentan una y otra vez a lo largo de la historia. Sin embargo, no permanecen inamovibles; por el contrario, al ser recontados se introducen rasgos propios del contexto histórico en que emergen, produciendo versiones diferentes. Tal es el caso del mito de Antígona. En este ensayo quisiera detenerme en Antígona furiosa, de Griselda Gambaro, y Usted está aquí, de Bárbara Colio, para observar cómo estas dramaturgas hispanoamericanas parten del mito ancestral para construir textos dramáticos diferentes, en los que el mito adquiere una dimensión significativa nueva, que responde a las nuevas circunstancias políticas y sociales, pero conserva algunas de sus características esenciales, como la presencia del héroe. 
Palabras clave: mito, Antígona, héroe trágico, ética, teatro latinoamericano.

Abstract

Myths tell so much about human condition that they are told on once and again through history. However, in that process they do not remain unchanged. On the contrary, as they are being told, some traits of the immediate historic context are introduced in them, producing different versions. Such is the case of the myth of Antigone. In this paper I would like to pay close attention to Griselda Gambaro's Antigona furiosa and Barbara Colio's Usted está aqui in order to see how this Latin-American playwrights, based upon the ancient myth, build different dramatic texts in which the myth adopts a new and meaningful dimension according to the new sociopolitical circumstances, but retaining some of its essential characteristics such as the presence of the hero.

Keywords: Myth, Antigone, Tragic Hero, Ethics, Latin American theater. 
Todos aqui iremos desapareciendo si nadie nos busca, si nadie nos nombra.

Todos aqui iremos desapareciendo si nos quedamos inermes sólo viéndonos entre nosotros, viendo cómo desaparecemos uno a uno.

[...]

Me llamo Antígona González y busco entre los muertos el cadáver de mi hermano.

SARA URIBE

$\mathrm{E}$ animal simbólico que es el ser humano ha construido un cúmulo de mitos que lo ayudan a comprender el mundo que lo rodea. Aun en los tiempos que corren, desacralizados y relativistas, la mitología griega constituye una fuente inagotable de riqueza simbólica, a la que se acude una y otra vez para la reflexión filosófica y la creación artística. Es tan grande la flexibilidad y polivalencia de los mitos griegos que con frecuencia se revitalizan para convertirlos en símbolos de problemas sociales o filosóficos de actualidad. ${ }^{1}$ El mito de Edipo, por ejemplo, le sirvió a Freud para elaborar una de sus más importantes aportaciones psicoanalíticas -el complejo de Edipo- y al sociólogo K. R. Popper le procuró la base para concebir el llamado "efecto de Edipo", que supone que "una predicción puede influir sobre el suceso predicho" (Popper, 2006: 27). De la misma manera, el mito de Sísifo se ha convertido, gracias a la interpretación hecha por Albert Camus, en la metáfora de la absurda condición humana, tan próxima al sentimiento del hombre contemporáneo.

${ }^{1}$ Vid. "La presencia del mito griego en nuestro tiempo" (1989), de José Lasso de la Vega. 
Otro de los mitos que más fascinación ha despertado en el mundo occidental es sin duda el de Antígona. Tanto es así que, una vez establecidos sus rasgos paradigmáticos en la tragedia de Sófocles, es prácticamente imposible dar cuenta de sus múltiples reelaboraciones artísticas, no exclusivamente teatrales, así como de los diversos estudios de índole filosófica, jurídica o estética que sobre él se han escrito a través de los siglos. Afirma Steiner, en su admirable ensayo sobre el personaje trágico, "Versiones teatrales, operísticas, coreográficas, cinematográficas y narrativas de 'Antígona’ se están produciendo en este mismo momento" (1991: 91). Y no hay indicios de que esto pueda cambiar en los años venideros.

De ahí la pertinencia de preguntarse por la razón de que la figura de Antígona haya sido tan productiva en Occidente; ¿qué valores encarna que la vuelven tan necesaria? La respuesta seguramente no es simple, pero no cabe duda de que hay algo esencialmente humano en el personaje, algo que tiene que ver con un heroísmo capaz de enfrentar a un poder arbitrario en aras de la fidelidad a los propios valores e ideales.

Su constante presencia lo largo de la historia hace pensar, en principio, que su significado va más allá de condiciones sociales específicas; que una vez establecido el mito por medio de Sófocles, el conflicto entre Antígona y Creonte -interpretado como el enfrentamiento entre la ley sagrada y la ley de los hombres, como entre la razón de Estado y el derecho del individuo, o bien como el choque entre la conciencia privada y el bienestar público- plantea un dilema ético que se antoja inherente a la condición humana. Sin embargo, al observar con más detenimiento sus distintas reelaboraciones artísticas, se advierte la marca de las condiciones históricas particulares en que surgen; ya que, como señala Jennifer Duprey, "The myth of Antigone is trans-historical, that is, it travels across history, not outside it" (2013: 2). 
Es notable cómo muchas de estas actualizaciones aparecen precisamente en épocas de crisis. Pensemos, por ejemplo, en las Antígonas que tienen como telón de fondo los conflictos por los que atravesó Europa a mediados del siglo pasado. En el contexto de la Segunda Guerra Mundial están la Antigone, de Jean Anouilh, estrenada el 4 de febrero de 1944 en París, durante la ocupación nazi, y la adaptación de Bertolt Brecht, escrita en 1947, pero cuya acción se sitúa en 1945. Otro tanto ocurre tras la Guerra Civil Española, con la instauración del franquismo: ahí están, como muestras significativas, La sangre de Antígona (1955), de José Bergamín, y La tumba de Antígona, de María Zambrano (terminada en 1964 y publicada en México en 1967).

En el ámbito latinoamericano, de la larga nómina de textos dramáticos que parten de este mito trágico ${ }^{2}$ me interesa destacar dos, que también se vinculan con circunstancias sociales particularmente conflictivas, marcadas por la violencia: Antígona furiosa, de Griselda Gambaro, ${ }^{3}$ y Usted está aquí, de Bárbara Co-

${ }^{2}$ Entre otras, Antígona Vélez, de Leopoldo Marechal, La ley de Creón, de Olga Harmony, Antígona, de José Watanabe, La pasión según Antígona Pérez, de Luis Rafael Sánchez, y Antígona-Humor, de Franklin Domínguez y Hernández.

${ }^{3}$ Narradora y dramaturga argentina nacida en 1928 . Ocupa un lugar destacado en el contexto teatral latinoamericano. Cuenta con una profusa obra literaria, de marcado compromiso político y social. Durante la dictadura militar se vio obligada a exiliarse en España, y su novela Ganarse la muerte fue prohibida por un decreto del general Videla. Entre sus obras teatrales destacan: Los siameses, El campo, Nada que ver, Sucede lo que pasa, La malasangre, Antígona furiosa y Morgan. A grandes rasgos, la obra de Gambaro es cercana a las principales corrientes teatrales europeas de los ańos 50, como el existencialismo, el teatro de la crueldad y el teatro del absurdo, sin que pueda afiliarse sin más a ninguna de ellas. Ha recibido numerosas distinciones, entre las que se encuentran el Premio Fundación Di Tella, el Doctorado Honoris Causa, concedido por el Instituto Universitario Nacional del Arte (IUNA), el Premio por la Paz "Azucena Villaflor" y el premio Atahualpa del Cioppo, otorgado por el Festival Iberoamericano de Teatro (FIT) como reconocimiento a su trayectoria artística. En 2010, 
lio. ${ }^{4}$ En ambos casos, las autoras toman como punto de partida la tragedia de Sófocles, pero aluden de manera clara al presente de la escritura: es decir, a la dictadura de Videla, en Argentina (con sus condenados sin juicio y sus "desaparecidos"), y a la generalización de la criminalidad y la corrupción que se sufre desde hace más de una década en nuestro país.

En este ensayo quisiera detenerme en estas dos obras para observar cómo un mito ancestral "literalizado" - es decir, asumido por un texto literario concreto- es recogido y reformulado por dos escritoras hispanoamericanas para construir textos dramáticos diferentes, en los que el mito adquiere una dimensión significativa nueva, que responde a las nuevas circunstancias políticas y sociales, pero conserva algunas de sus características esenciales. Particularmente, deseo centrar la mirada en cómo el conflicto ético se transforma, pero pervive la figura del héroe en estas obras que, sin ser tragedias en un sentido estricto, conservan este elemento fundamental del género.

pronunció el discurso inaugural de la Feria del Libro de Fráncfort, Alemania, en nombre de los escritores argentinos, en la edición en que su país fue el invitado de honor.

${ }^{4}$ Dramaturga y directora teatral nacida en 1969. Ha sido becaria del Fondo Nacional para la Cultura y las Artes de México y ha obtenido diversos reconocimientos en México y el extranjero como el Premio Estatal de Literatura de Baja California en 2002 y el Premio María Teresa León en 2004, otorgado por la Asociación de Directores de Escena de España y el Ministerio de la Mujer, entre otros. Aunque en la actualidad radica en la Ciudad de México, se le considera parte del llamado Teatro de la Frontera Norte (en buena medida propiciado y articulado por el dramaturgo Hugo Salcedo). Entre sus obras más importantes destacan: La habitación, La boca del lobo, Pequeñas certezas, Cuerdas y A propósito de Alicia. 


\section{Antígona furiosa}

Griselda Gambaro ha explorado en su teatro la confrontación del poder abusivo, así como la relación víctima-perseguidor, en muy diversas modalidades. La crítica ha observado, además, que en su producción dramática de los años ochenta los personajes femeninos tienen una importancia notable en el planteamiento y desarrollo de los conflictos. En esos años,

las mujeres desempeñan los papeles activos, rebeldes. Durante su persecución y tras su muerte, continúan denunciando a la autoridad, sus voces muertas se escuchan no como ausencia sino como presencia. La paradójica víctima que muere mas no muere domina la escena... (Taylor apud Tarantuviez, 2007: 138).

Y eso es precisamente lo que ocurre con Antígona; quizá una de las protagonistas más intensas y contestatarias del teatro de Gambaro.

Tal como se explica en el programa de mano entregado en el estreno, la autora "arma una nueva Antígona fuera del tiempo para que paradójicamente nos cuente su historia en su tiempo y en el nuestro" (apud Mogliani, 1997: 98), difuminando así las fronteras entre el presente argentino y el pasado tebano. Y el presente argentino, el del estreno de Antígona furiosa en 1986, vivía las consecuencias de la dictadura militar encabezada por Jorge Rafael Videla (1976-1983). Así, la autora reelabora el mito griego para hablar de la dolorosa situación que atravesaba su país por esos años, aprovechando el texto social implícito (Pellarolo, 1992: 79). Es decir, que sin necesidad de referirse directamente a la realidad extraliteraria, el contexto de la enunciación marcó la representación artística con la fuerza de lo no-dicho pero sobreentendido. De este modo Antígona evoca a las madres de la Plaza de Mayo que alzaron la voz e 
hicieron de la incansable búsqueda de sus hijos desaparecidos un acto de rebelión política. ${ }^{5}$

La obra se abre con una imagen contundente: "Antígona ahorcada. Ciñe sus cabellos una corona de flores blancas, marchitas. Después de un momento, lentamente, afloja el lazo de su cuello, se acomoda el vestido blanco y sucio. Se mueve, canturreando" (Gambaro, 2003: 197). Los lectores/espectadores, conocedores del mito, suponemos que la tragedia ha ocurrido ya, y que la autora sitúa el comienzo de su obra justo en el momento en donde la tragedia clásica se cierra: es decir, con el suicidio de Antígona, que a su vez precipita los de Hemón y Eurídice. Sin embargo, todo volverá a ocurrir, gracias a la evocación de los personajes.

Con una gran capacidad de síntesis dramática, la historia, simultaneando pasado y presente, se desarrollará en un solo acto, con sólo tres actores, quienes en principio representan tres personajes pero que, a lo largo de la obra, se desdoblan en otros tantos: el Corifeo, al ponerse una carcasa asume "el trono y el poder" (196), la personalidad de Creonte; Antinoo (personaje que no aparece en la tragedia de Sófocles) por momentos asume la función del coro, y la propia Antígona, quien le da voz a Hemón, en la escena con su

${ }^{5}$ La crítica ha distinguido ya con claridad esta relación. Patrick Dove ha senalado que "Gambaro's theatrical appropriation of Antigone clearly points to the public presence of the Madres de la Plaza de Mayo during the time of dictatorship. Gambaro's Antígona metonymically represents a group that, in its weekly occupations of the symbolic center of Argentine civic space, effectively transformed remembrance and maternal love -traditionally regarded as private and as "women's work"-into political signifiers" (2013: 43). Por lo demás, la propia Griselda Gambaro afirmó en una entrevista: "yo iba a hablar con la voz de una mujer latinoamericana y con las voces de tantas mujeres que en mi país han hecho lo mismo que Antígona, que desobedeció la orden del rey Creonte y arrojó un puñado de tierra sobre el cadáver de su hermano, suficiente como para cumplir con la tradición de dar sepultura a sus muertos. Antígona es cada una de las Madres de la Plaza de Mayo que han pagado con su vida la desobediencia" (Navarro Benítez, 2001: s.p.). 
padre, y a Ismene, mediante lo que en la narrativa sería el discurso indirecto y el indirecto libre. No obstante, a pesar de la considerable reducción de personajes y situaciones, Gambaro mantiene con sus mi temas básicos (aunque no todos se representan directamente en escena, algunos son solamente referidos) buena parte de la trama que proviene de la tragedia sofoclea: la discusión de las hermanas, el enfrentamiento de Antígona y Creón, el ruego de Hemón a su padre, el lamento de Antígona, la profecía de Tiresias y los vanos esfuerzos de Creonte por evitar la desgracia. Sin embargo, de entre las muchas y fundamentales variaciones que hay en Antígona furiosa respecto de su referente griego quisiera seńalar una que transforma por completo la valoración ética del conflicto producido por las posturas encontradas de Antígona y Creonte.

En la tragedia de Sófocles vemos dos formas diferentes de enfrentar el conflicto, aunque en ambas hay una especie de simplificación de los compromisos y apegos afectivos. Los dos protagonistas enfrentan una crisis con sistemas de valores incompatibles y parciales; poseen un criterio simple, y sus preocupaciones se encuentran ordenadas respecto de dicho criterio:

Hay cosas que no reconocen, obligaciones que niegan, situaciones para las que utilizan nombres que no son los más pertinentes ni los más verdaderos. Antígona adopta una decisión cuyo contenido es con mucho el más aceptable; pero tanto ella como Creonte adolecen deuna significativa estrechezde perspectivas (Nussbaum, 2003:91).

Creonte, en tanto representante de la ciudad, debe impedir el sepelio de Polinices dentro de los márgenes del Ática, porque se trata no sólo de un enemigo, sino de un traidor, pero olvida los lazos de amor que unen a las personas, y deja por completo de lado sus propias obligaciones familiares. La oposición amigo-enemigo no admite matiz ni excepción. Para él 
Sólo está «bien» lo que sirve a la ciudad; «mal», lo que la perjudica; [...] La "piedad", virtud importante, es rebajada al vínculo cívico, y los dioses, obligados a no honrar más que a los ciudadanos muertos por la patria. Es esta visión empobrecida y simplificada de su propia ciudad la que lleva a Creonte a su perdición. Su cambio tardío hace de él un héroe que aprende demasiado tarde (Ricoeur, 2006: 263).

Desde este punto de vista, el error principal de Creonte consiste en despersonalizar al Otro y simplificar los valores mediante la negación de ciertos aspectos del mundo. No obstante, otro tanto ocurre con Antígona, quien también niega la complejidad de la situación. Para ella sólo importa el pequeño círculo de su familia y carece completamente de importancia lo que queda fuera: la nofamilia. "Si escuchásemos sólo a Antígona -sostiene Nussbaumno sabríamos que se ha producido un conflicto bélico, ni siquiera que algo llamado 'ciudad' ha estado amenazado" (Gambaro, 2003: 106-107). ${ }^{6}$

Como vemos, en la tragedia sofoclea se establece cierta equivalencia entre el proceder de Antígona y el de Creonte. Ambos transgreden un orden al pasar por alto la esfera de lo ético representada por el otro, pero que inevitablemente existe en ellos mismos. Ver a Creonte como el tirano cruel y a Antígona como la heroína virtuosa es reducir y simplificar el problema. ${ }^{7}$ Ninguno tiene razón en

${ }^{6}$ Ricoeur ha advertido también la estrechez de la postura de Antígona. Su visión del mundo resulta "tan limitada y carente de contradicciones internas como la de Creonte. Su manera de zanjar entre philosy ekhthros es tan rígida como la de Creonte; sólo cuenta el vínculo familiar, por otra parte magníficamente concentrado en la 'fraternidad"' (2006: 264).

${ }^{7}$ Pese a todo, es cierto que nuestras preferencias apuntan claramente hacia Antígona; porque no se puede negar que ante un dilema hay mejores y peores razones para actuar, a pesar de que la realidad sea a tal punto compleja que cualquier postura que pretenda simplificarla será inexcusablemente problemática e insatisfactoria. A Creonte lo mueven, amén de una razón de Estado, la ira y la arrogancia, no exentas de misoginia; mientras que la transgresión de Antígona 
un sentido absoluto, por lo que no es posible resolver de manera simple el conflicto.

Me ha parecido importante plantear las consideraciones anteriores para, a la luz de ellas, poder afirmar que el tenso equilibrio que hasta cierto punto se establece entre los protagonistas de la tragedia sofoclea desaparece en la obra de Gambaro -y en la de Colio, como veremos más adelante- para privilegiar la figura luminosa de Antígona. Veamos cómo ocurre, observando algunas de las características significativas de la composición dramática de la obra.

Dije líneas arriba que en Antígona furiosa se difuminan las fronteras entre el pasado y el presente. Esto se logra mediante la confluencia de dos planos de realidad que se sobreponen e intersecan en diversos momentos del drama: uno es el del presente de la enunciación, es decir el de la Argentina de finales de los años ochenta del siglo veinte. A ese universo pertenecen Antinoo y el Corifeo. Ambos personajes aparecen tomando café, "vestidos con trajes de calle” (197) y hablando en el español de la norma argentina contemporánea. El otro es el del pasado tebano de la tragedia clásica, el universo de Antígona.

Es notable el alto contraste en los tonos que emplean Antinoo y el Corifeo, por un lado, y Antígona, por el otro. Los primeros, con sus sarcasmos y payasadas, se expresan con un lenguaje más en consonancia con la tradición del grotesco; mientras que Antígona conserva el lenguaje grave y elevado característico de la tragedia clásica. El contrapunto que se establece entre la presencia trágica de la heroína y la trivialidad de dos hombres sentados a la mesa de un café es una de las elecciones artísticas que le permiten a Gambaro la confluencia de la historia contemporánea y el mito (Duroux y Urdician, 2012: 86-87).

no sólo supone una comprensión mayor de la comunidad y sus valores, sino que además realiza sus actos piadosos en soledad, desde el compromiso individual, sin ejercer violencia contra nadie. 
A lo largo de la obra, Antinoo y el Corifeo desempeñan un papel doble: por una parte son espectadores del sufrimiento de Antígona y por la otra participan de la acción dramática asumiendo el papel de Creonte, del Coro o de Tiresias. Su actitud sarcástica y deshumanizada, salpicada de juegos burlescos, los hace parecer marionetas sin complejidad psicológica alguna. En su rol de testigos, sus valoraciones de los hechos remiten a la realidad extraliteraria del estreno de la obra en 1986, cuando las fuerzas más conservadoras de Argentina pedían darle la vuelta a la página, perdonar los crímenes perpetrados por la dictadura y emprender lo que llamaron un proceso de reconciliación nacional, justo en el momento en que la sociedad, en su conjunto, comenzaba a conocer los detalles más escalofriantes de la represión militar.

CoRifeo (se acerca): ¿Qué pretende esta loca? ¿Criar pena sobre pena?

Antinoo: Enterrar a Polinices pretende, jen una mañana tan hermosa!

$[\ldots]$

Antígona: ¡Se dieron muerte con las espadas! ¡Eteocles, Polinices! ¡Mis hermanos, mis hermanos!

Corifeo (vuelve a la mesa): Siempre las riñas, los combates y la sangre. Y la loca esa que debiera estar ahorcada. Recordar muertes es como batir agua en el mortero: no aprovecha. Mozo, jotro café! Antinoo (tímido): No hace mucho que pasó.

Corifeo (feroz): Pasó. ¡Y a otra cosa!

Antinoo: ¿Por qué no celebramos!

Corifeo (oscuro): ¿Qué hay para celebrar?

Antinoo (se ilumina, tonto) ¿Que la paz haya vuelto! (199-200).

Así como Antígona es tildada de loca, con gran virulencia, por "recordar muertes", las madres de la Plaza de mayo fueron tachadas de locas por tener el coraje de denunciar, aun en plena dictadura, el secuestro y la desaparición de miles de personas, en su mayoría 
jóvenes. Su locura consistió también en exigir la reaparición con vida de los desaparecidos, cuando la mayor parte de la sociedad sabía que habían sido ejecutados sumariamente, y en no haber aceptado indemnización económica alguna por parte del Estado (Nabuco y Amarante, 2011: xx-xxi).

Cuando Antinoo y el Corifeo participan en la acción, asumiendo la función del Coro, se distancian también de su referente griego, ${ }^{8}$ mofándose con crueldad de la joven, incluso en los momentos de mayor dolor. Al final de la obra, por ejemplo, cuando Antígona se dirige, asustada, hacia su tumba, tiene lugar el siguiente diálogo:

Antígona: Como Niobe, el destino va a dormirme bajo un manto de piedra.

Corifeo: Pero Niobe era una diosa y de dioses nacida. Nosotros mortales y nacidos de mortales.

AnTINOO: ¡Es algo grandioso oírle decir que comparte el destino de los dioses!

(Rien)

Antígona: ¡Se ríen de mí!

Corifeo: ¡No, no!

(Ríen)

${ }^{8}$ El coro de Sófocles está compuesto por ancianos nobles de la ciudad que representan a la polis. Y si bien es cierto que al comienzo de la obra adoptan una actitud muy poco solidaria con la joven heroína y en sus primeros cantos consideran junto con Creonte que el entierro de Polinices constituye un acto de rebelión política, más adelante, tras el encuentro del tirano con Tiresias, el coro recapacita y, asustado, le advierte a Creonte que el augur no se ha equivocado nunca y le sugiere prudencia: debe liberar a Antígona y dar sepultura a su hermano. Pero ya no hay forma de parar la rueda de fuego. Finalmente, tras los sucesos desgraciados, el Corifeo reflexiona sobre lo sucedido, y concluye: "Aquel que se muestre soberbio y lenguaraz grandemente sus culpas expiará y con los años tendrá que aprender sensatez" (2011: 450). Cito la Antígona de Sófocles en la versión rítmica en español de Manuel Fernández-Galeano. Remito a esta obra sólo con los números de página entre paréntesis. 
Antígona: ¿Por qué ultrajarme antes de mi muerte, cuando respiro todavía!

Corifeo: Bueno, ¡fue una broma! ¡No te ofendas! (Tentados, rien apretados los labios, tragándose la risa)

AnTígona: Oh, ciudadanos afortunados, sean testigos de que nadie me acompaña con sus lágrimas...

Corifeo: ¡Dios mío, empieza a compadecerse! (Intenta huir) (210).

Nada hay de reflexivo o empático en el "coro" de Gambaro. Asume sin ambages la perspectiva ideológica del dictador y se burla, cruel, de los sufrimientos de una Antígona que camina entre muertos. “Cadáveres! ¡Cadáveres! ¡Piso muertos! ¡Me rodean los muertos! Me rodean... me abrazan... Me piden... ¿Qué?” (200). Ambos personajes masculinos forman parte del grupo que se inclina ante el poder y "mueve la cola como perros" (201). Serviles y cobardes, dispuestos a justificar el crimen y la injusticia, representan lo peor de ciertos estratos de la sociedad argentina (Dove, 2013: 43).

Otro de los cambios fundamentales que introduce Gambaro en su obra (respecto de la de Sófocles) -y que evocan a la Argentina de los ańos ochenta más que a cualquier pasado mítico- es la connivencia de Tiresias, en tanto que representante de la Iglesia, con la autoridad, y el hecho de que Creonte no sufra un proceso de anagnórisis en el que reconozca sus errores y se convierta, como su antecedente griego, en otro desdichado Edipo. ${ }^{9}$ El Corifeo/Creonte de Gambaro no sólo permanece en el poder, gozando los manjares y los vinos, sino que ¡perdona a Antígona!, por todo lo que él ha sufrido: "Corifeo: ¡Los perdono! ¡No saben lo que hacen! Preten-

9 “Creonte: ¡Ay, ay de mí! Ningún mortal/ podrá cargar con la culpa mía./ Yo, infortunado, te maté, hijo mío,/ ésta es la verdad ¡Eh, servidores,/ llevadme de aquí cuanto antes, conducidme lejos,/ pues ya no existo, ya no soy nadie!" (Sófocles, 2011: 449). 
den condenarme, a mí, que di mi hijo, mi esposa, al holocausto. Antígona, que trajiste tantos males sobre mi cabeza y mi casa, jte perdono!" (216).

Como vemos, no puede establecerse ninguna equivalencia ética entre el proceder de Antígona y el de Creonte, como ocurría en la tragedia de Sófocles, ni atribuirles dos puntos de vista igualmente parciales (me parece que la realidad de la Argentina de los años ochenta no lo permitía). En la obra de Gambaro, la joven se enfrenta al cinismo del tirano y de su séquito; opone su humanidad a la barbarie. Antígona está dispuesta, pues, a enterar a su hermano, a salvarlo no sólo de las fieras sino del olvido:

Antígona: También se encadena la memoria. Esto no lo sabe Creonte ni su ley. Polinices, seré césped y piedra. No te tocarán los perros ni las aves de rapiña. (Con un gesto maternal) Limpiaré tu cuerpo, te peinaré. (Lo hace) Lloraré, Polinices... lloraré... ¡Malditos! (202).

Está dispuesta a sacrificarse a sí misma por sus valores, a enfrentar sola al poder y su maquinaria. Muere sin retractarse, aunque la aguijoneen el dolor y el miedo. Su vulnerabilidad en la virtud contribuye a hacer de ella la más humanamente rica de los personajes.

Comparto el punto de vista de Rodríguez Adrados cuando afirma que "el héroe trágico es uno de los tipos ideales creados por Grecia que mejor expresan su espíritu y que mayor proyección han alcanzado históricamente; con rasgos más o menos diferentes continúa viviendo en nuestra escena, en nuestra filosofía, en nuestra vida misma" (1962: 11). En la obra de Gambaro, las circunstancias de Antígona se han transformado, pero permanece en ella la dignidad del héroe trágico, capaz de arrostrar los grandes conflictos. Como sus antepasados griegos, ya sea que fracase o que triunfe, su empeño va acompañado siempre de un gran dolor y de la necesidad de tomar decisiones que el común de los mortales in- 
tenta evitar. Así vemos a Antígona, en la soledad de las decisiones trascendentes, poniendo en evidencia la fragilidad y la grandeza del ser humano:

Antígona: Delante de Creonte, tuve miedo. Pero él no lo supo. Señor, mi rey, ¡tengo miedo! Me doblo con esta carga innoble que se llama miedo. No me castigues con la muerte. Déjame casar con Hemón, tu hijo, conocer los placeres de la boda y la maternidad. Quiero ver crecer a mis hijos, envejecer lentamente. ¡Tengo miedo! (Se llama con un grito, trayéndose el orgullo) ¡Antígona! (Se incorpora, erguida y desafiante) ¡Yo lo hice! ¡Yo lo hice! (204).

Finalmente, me parece importante señalar también que Antígona furiosa comienza y termina con la muerte/suicidio de la protagonista, con lo que la acción, a despecho de todos los rasgos que apuntan a unas circunstancias históricas determinadas, pareciera situarse en una especie de presente dilatado, el cual abarca una realidad de injusticia y opresión que se ha sufrido no sólo en la Argentina de los años ochenta sino por décadas en toda América Latina. Así, en la medida que no cambien las condiciones de infamia e ilegalidad que campean en nuestros países, se repetirá el absurdo final donde el tirano es quien disculpa a la víctima. Sin embargo, esta Antígona querrá siempre enterrar a su hermano, "Aunque nazca mil veces y él muera mil veces". Es la voz que se rebela ante la burla y la injusticia, que rechaza la misericordia "que le sirve de disimulo a la crueldad". Porque "el odio manda", es necesaria su muerte, "con furia" (217).

\section{Usted está aquí}

En el contexto teatral mexicano, una de las más recientes apropiaciones de la figura de Antígona la encontramos en Usted está aqui (2010), de Bárbara Colio. Esta obra, situada formalmente en 
Tebas, alude con prístina claridad a la realidad nacional contemporánea: al imperio de la violencia y la impunidad, a la proliferación de asesinatos y secuestros que suceden ante la incapacidad -cuando no la anuencia y complicidad- del Estado mexicano. En la actualidad, México es el país con más secuestros en el mundo, también figura entre los primeros lugares de muerte y tortura de las víctimas que se resisten al delito o cuyos familiares no cumplen con las condiciones exigidas para su rescate. A esta realidad, precisamente, apunta la obra de Colio, cuyo referente concreto, de gran trascendencia social, fue el secuestro y asesinato en 2005 del joven empresario Hugo Alberto Wallace Miranda. Una de las razones de que este caso haya tenido especial resonancia recae en la madre de la víctima, la cual encabezó la búsqueda de su hijo, colocó anuncios espectaculares con las imágenes de los supuestos delincuentes y ofreció grandes sumas de dinero a cambio de información que llevara a su captura.

El argumento básico de la obra de Colio -compuesta por dieciséis escenas, cada una con un título- puede dividirse en dos partes. En la primera, ajena por completo al referente griego, el personaje de Ana -quien como veremos cumple la función de Antígona en un nuevo contexto- tiene como objetivo dar con el paradero de su hijo, secuestrado tres meses atrás. Sin embargo, en la segunda parte, tras saber que el joven fue asesinado la noche misma de su secuestro, la protagonista, incapaz de aceptar que todo ha terminado, y a pesar de las súplicas de su hermana y de las amenazas anónimas que recibe, decide que no cejará en su búsqueda hasta encontrar el cadáver de su hijo y sepultarlo:

No voy a detenerme hasta encontrarlo, cada parte, cada uńa, cada uno de sus cabellos, los voy a encontrar y enterrar. Con su nombre bien escrito sobre su cuerpo. Y no me importa si nadie lo puede entender, no me importa, porque no voy a escuchar nada más que 
no sea el sonido de la tierra cayendo sobre el cuerpo de mi hijo (Colio, 2010: 42-43).

Es en este punto cuando Bárbara Colio se apropia del motivo básico de la Antígona clásica, ya que, a partir de la certeza de la muerte del joven, Ana sólo tiene un objetivo: "Yo le di mi cuerpo para que naciera, yo misma le daré un hueco en la tierra para que descanse en paz" (43). Salta a la visa, sin embargo, que no se trata de una adaptación del mito, en estricto sentido, sino de la apropiación libre de algunos de sus elementos constitutivos, que la autora aprovecha para crear un nuevo texto dramático. Por esta razón, será conveniente sopesar qué elementos permanecen, aunque modificados, y qué sentidos adquieren en este nuevo universo dramático. ${ }^{10}$

Suele aceptarse que en la tragedia griega el coro representa a la ciudad (la polis) y, en consecuencia, habla por ella; es un ente colectivo que, ya sea que participe directamente de la acción, o no, habita un espacio público en el que se plantean los asuntos más importantes para el bienestar común. En la obra de Colio, se percibe la presencia de la ciudad en las voces de algunos locutores de televisión, que en cierta forma cumplen las funciones tanto del Coro como del adivino Tiresias. Dichas voces - que carecen de un nombre propio y que se denominan por la función que cumplen (Locutor y Locutora) - nos informan de los extrańos sucesos naturales que están ocurriendo en Tebas, y que en un primer momento no se saben interpretar: "Cientos de pájaros cruzaron nuestro cielo [...] Esta desconcertante emigración de aves fuera de temporada tiene confundidos a los expertos que aún no pueden asegurar las

10 "Even though Colio's play cannot be fairly described as a new version or adaptation of Sophocle's Antigone, resonances of Greek tragedy can be heard throughout the play, and even some quotations from Antigone can be found scattered along its pages" (Nelli, 2012: 55). 
causa del éxodo" (13). Un poco más adelante, estos mismos personajes nos comunican que la situación se agrava: la ciudad comienza a padecer altas temperaturas, sequías, enfermedades; en ciertos suministros de agua potable ha aparecido una extraña bacteria que ha ocasionado ya algunos decesos, y las aves rezagadas aparecen muertas... (16).

Para la novena escena, titulada "Oráculo", el Locutor considera dos explicaciones al éxodo masivo de aves: una, de aspiraciones científicas, atribuye el fenómeno a la contaminación, y otra, "apocalíptica", señala que "es un claro aviso de peores calamidades y contingencias que azotarán a Tebas en la presente época”. "Cada quien le dará la razón a uno u otro grupo según su criterio -continúa el Locutor-, pero lo cierto es que a los pájaros, cada mañana se les extraña” (24). Estas predicciones no sólo evocan las del ciegovidente del mito de Antígona, tal como lo elabora Sófocles, ${ }^{11}$ sino que nos hablan de la gravedad de la situación, de un desorden que tiene consecuencias nefastas, de naturaleza casi cósmica.

Llama la atención, sin embargo, que en el texto de Colio, el espacio público del coro, ocupado ahora por los locutores, deje de ser el lugar privilegiado del diálogo y la discusión ciudadana, en que se construye la polis. Por el contrario, las voces que orientan el criterio público son tristes mensajeras del poder y de la ideología dominante, y de ninguna manera tienen la dignidad de los nobles viejos tebanos del texto de referencia. En la séptima escena, estas voces anuncian a la comunidad lo que ocurre en la ciudad, pero las noticias sobre la inseguridad generalizada que se vive en el país,

${ }^{11}$ Cito fragmentos del parlamento de Tiresias en la tragedia de Sófocles: "Cuando ocupé el asiento donde observar solía desde siempre las aves que allí acuden a mí, escuché un ruido insólito: los pájaros piaban en una algarabía nerviosa y malsonante y sin duda indicaba su ruidoso aleteo que entre sí se atacaban con sus garras y herían. [...] Y así los dioses ya no aceptan de nosotros sacrificios ni súplicas ni las carnes quemadas, ni traen buen augurio las voces de los pájaros, que han bebido el humor sangriento del difunto" (2011: 438-439). 
donde cualquiera puede ser víctima del secuestro, alternan con anuncios baladíes sobre la inauguración de una plaza comercial, donde consumir equivale a ser feliz.

LOcuToR: En sólo 1.2 por ciento de los plagios denunciados se encuentra a las víctimas. Y sólo en 0.7 por ciento los responsables son castigados.

[...]

LOCUTORA: Clima perfectamente acondicionado. Áreas recreativas, alimentos orgánicos y más de 300 establecimientos donde, le aseguramos, encontrará todo lo que usted necesita. Todo (2010: 18).

Resulta impresionante observar el grado de naturalización que ha logrado la violencia en el universo recreado por Colio. En un mundo lleno de datos y cifras al alcance de todos - "Números" es el título de la escena-, los seres humanos parecen volverse insensibles al crimen y al horror. Y los medios de comunicación contribuyen al proceso de enajenamiento de la sociedad, creando ciudadanos autómatas y conformistas, incapaces de mirar críticamente la realidad. Unas escenas adelante, tras un momento clave de la obra en el que se contraponen las posturas con que Ana y su hermana Isaura enfrentan la crisis, los locutores vuelven a la carga insistiendo en la idea de que la inauguración del centro comercial, donde se puede encontrar todo lo necesario para ser feliz, no sólo es señal de bienestar y progreso, sino que es el lugar ideal para olvidar "cualquier inclemencia" (43).

Sin duda, uno de los elementos más importantes del mito que la autora retoma se encuentra en su personaje protagónico, Ana, quien posee características que evocan las de los héroes trágicos. ${ }^{12}$

${ }^{12}$ Coincido completamente con Florencia Nelli cuando apunta que "Aside from obvious allusions to the tragedy, there is a deeper connection linking this play to Sophocle's drama. It is a somehow inner substance, a shared matter, a feel- 
Recordemos que si en la antigüedad estos personajes extraordinarios encarnaban en seres superiores, por lo general procedentes de la leyenda heroica, con el paso de los siglos fueron perdiendo esa dimensión mítica, pero conservaron la grandeza espiritual que les permite enfrentar conflictos decisivos, en un mundo en el que se mueven fuerzas terribles que amenazan la existencia de las personas. En la tragedia contemporánea, también el "hombre de la calle" logra, bajo determinadas circunstancias, alcanzar la estatura del héroe: se niega a cruzarse de brazos ante la injusticia, está dispuesto a luchar sin reservas, a señalar con el dedo al enemigo y entregar su vida, si es necesario.

En el texto de Colio, las fuerzas oscuras a las que se debe enfrentar Ana, una simple maestra de primaria, ya no guardan relación con lo numinoso, sino que se vinculan con problemas sociales perfectamente reconocibles: el crimen organizado, la falta de un estado de derecho, la corrupción... Con todo, a pesar del miedo, desde la primera escena vemos al personaje dispuesto a arrostrar cualquier peligro con tal de recuperar a su hijo: no sólo buscará a los criminales, que llegan a amenazarla con una pistola en la sien, sino que enfrentará al Estado mismo, que encubre al culpable e intimida a los ciudadanos.

Por otra parte, es importante constatar que en Usted está aqui también se "desdibuja" el conflicto fundamental, entre Antígona y Creonte, que se planeta en el mito clásico. El personaje del Señor, que asume el poder presidencial en la obra de Colio, no llega a tener la estatura del que sería su contraparte en la tragedia de Sófocles. Casi tímido al principio -no le es fácil apropiarse de la silla, símbolo del poder presidencial en México-, tiene "buenas intenciones" al comienzo de la obra; sin embargo, poco a poco

ing, an idea, something that we find inside Ana's character and that lies also in Antigone's: the force that drives them, the conviction. They are certain of something; they are determined women" (2012: 61). 
las circunstancias lo rebasan: "quejas y quejas es todo lo que recibo" (44). No es hasta que la "silla" le resulta cómoda, es decir, hasta convertirse en un demagogo más, lleno de discursos vacuos, cuando se adapta sin más al estado de cosas. Por lo tanto, ante la exigencia de Ana por hacer justicia, él responde:

[SEÑoR:] Créame que si fuera cosa de dar una sola orden, ya la habría dado. Es más, en muchos casos lo hubiera hecho. A estas alturas sería un héroe para Tebas ¿no? Pero eso es... querer ser un héroe imposible. Hay mucho que hacer en esta ciudad. Y lo voy a hacer. De eso puede estar segura. Seguiremos de cerca su caso (23).

Es claro que no es un "héroe" ni tiene el menor interés en serlo. Por el contrario, lejos de tener una conducta ejemplar, a lo largo de la obra no sólo promete cosas que no cumplirá, sino que protege y libera a los delincuentes que la propia Ana entregó a la justicia: "Hicimos lo posible apegados a la ley -afirma el Señor-, pero no podemos retenerlos por más tiempo. Su familia pagó la fianza. Lo siento, de verdad, lo siento mucho. Se seguirá otra línea de investigación" (46).

En cambio, en la obra de Colio se le otorga un espacio muy importante al personaje de Isaura (Ismene); también, se le confiere gran importancia al conflicto que surge entre las hermanas y al dilema ético de fondo. La relación entre ambas se perfila desde el comienzo de la obra: fueron cómplices desde niñas, compartieron juegos y aventuras, aunque siempre fue Ana la que los inventaba e Isaura quien los seguía. En la primera escena en que interactúan, Ana da muestra de su carácter cuando le comunica a su hermana que buscará ella misma a los secuestradores de su hijo; sabe que eso es peligroso pero tiene que hacerlo (11-12). Isaura, a pesar de encontrarse muy asustada, se muestra solidaria, y secunda la enorme tarea que se ha impuesto la protagonista. 
En la décima escena, es Isaura quien a la postre le comunica a su hermana que su hijo ha muerto. Los parlamentos entre ambas se suceden sin que Isaura encuentre el modo de dar la noticia. Hacia el final del encuentro, Ana expresa con ímpetu, en un alud de palabras, la certeza que tiene de que su hijo vive. Cito las breves intervenciones de Isaura, que se intercalan con la exaltada elocuencia de Ana, y que dan perfecta idea de la dificultad emocional de su tarea: "Lo sé. Lo sé. (La abraza) Estoy contigo. [...] ¿Qué dices? [...] Escúchame [...] Ana, es inútil. [...] Está muerto. [...] Detuvieron a la mujer. Declaró. Lo mataron esa misma noche" (31-32). Como puede observarse, Bárbara Colio consigue que se perciba con claridad la intensidad de las emociones que viven los personajes sin necesidad de verbalizarlas explícitamente; por lo que el lector está en condiciones de completar la escena mediante una representación virtual, cargada emocionalmente, pero contenida.

Conforme la trama avanza, Ana decide que no puede descansar, que a pesar de su enorme sufrimiento debe continuar con la búsqueda, ahora del cuerpo de su hijo. Isaura no entiende; es la voz de la razón: él ha muerto y no hay modo de cambiar esta realidad; pero ellas aún alientan y deben intentar recuperar sus vidas. Por si fuera poco las amenazas que han sufrido no cesan: la policía protege a los delincuentes; ellas deben parar.

Ana: Isaura, lo dices como si me aferrara a algo absurdo, a algo excepcional. Quiero el cuerpo de mi hijo, enterrarlo. ¿Eso te parece tan estúpido como para no seguir?

Isaura: ¡Aquí estamos otros! ¿No nos ves? Cada día son más las llamadas telefónicas amenazándonos. No todo el mundo está de tu lado. Es increíble pero así es. Hasta la familia del tipo ése te está acusando de, loca, de... (40). 
La ruptura entre las hermanas llega cuando Ana afirma que no tiene miedo a morir; Isaura, sí. Sin embargo, la autora le cederá la palabra a esta última: ella suplica por el bien de todos y muestra, en medio del miedo que la atenaza, su enorme capacidad de amar. En síntesis me parece que Colio le confiere a Isaura una dimensión emocional y una complejidad que la vuelven un personaje tan entrañable como el de Ana, pero con el que el espectador puede más fácilmente identificarse. ¿Cuántos de nosotros tendríamos el valor de un héroe? Seguramente no muchos.

En la última escena en que aparece, Isaura "dialoga" con un hombre mayor que no profiere una sola palabra. Ambos se hallan en un centro comercial, frente a un plano que indica "usted está aquî". Sin embargo, esta información no les sirve para encontrar la salida. En este momento se construye una imagen escénica que simboliza la pavorosa realidad que la mayor parte de los mexicanos vive sin lograr dar con la salida.

En la última escena de la obra, en la que Ana y el Señor hablan frente a los medios de comunicación, tiene lugar un rompimiento de la fábula que da paso a otro plano de ficción, que se pretende "la realidad": "un teléfono celular suena"y la acción se interrumpe (62). Los actores que interpretan a Ana y al Señor dejan de "actuar", y a partir de ese momento, y hasta el final de la obra, dialogan la Actriz 1 y el Actor 1 .

A pesar de que se rompe la ficción primera, los parlamentos del nuevo plano de realidad -el de los actores que realizan una representación teatral- configuran una situación no del todo realista. La Actriz se confiesa incapaz de actuar bien el papel de Ana, porque no puede sentir lo que ella siente. Le molesta, además, que no se llame a las cosas por su nombre: “¿Tebas?”... Si es aquí y ahora, en la realidad compartida con el público, donde las desgracias ocurren: “¿A qué diablos viene toda esa gente?” -se pregunta. "Este barrio está de la chingada. Te obligan a apagar el teléfono, 
sales a media noche, a ver si tu coche está donde lo dejaste. Tomar un taxi ¡Ja! Menos llegas” (63). Súbitamente la Actriz decide irse, pero, como Isaura en la escena del centro comercial, no encuentra la puerta de salida. El Actor la detiene para decirle que tiene una pequeña hija de 12 años, a quien describe con dulzura. En este momento ella comienza a narrar una escena que parece hipotética en un principio: "Una niña duerme sola. Su famoso padre está actuando aquí, lo dice el cartel de afuera. [...] Las bardas se saltan, las ventanas se rompen, los gritos no se escuchan, las cerraduras... ¿Cuántas cerraduras has puesto en tu casa?” Describe los pasos que podrían estar dando en ese mismo momento los delincuentes para secuestrar a la niña. “¿Tú qué harías?”, pregunta ella. “¿La buscarías por tu cuenta o acatarías el destino de 'esperar y confiar?’” (65). Con estos parlamentos se lleva al máximo de tensión no sólo al personaje masculino sino al lector/espectador que se siente interpelado por la pregunta en segunda persona, expresada en el plano de ficción de la "realidad" que, dada la construcción artística de la escena, compartimos con los personajes. A este recurso teatral se suma la reiterada alusión a una realidad común, que se desprende del deíctico de la frase que da título a la obra "usted está aquî", y que aparece con algunas variantes en múltiples ocasiones a lo largo de la obra.

La escena prosigue con un brevísimo intento por parte de ambos actores de continuar la "ficción", pero el teléfono suena nuevamente...

Cambio de luz. Se regresa al espacio dramático anterior.

El Señor está firme. Un momento. Rompe la convención. Sale rápidamente. Fuera de escena, lo escuchamos contestar su teléfono.

SEÑor: (Off) ¿Bueno?... ¿Bueno?... No... 
Desconcierto de los otros actores tras bambalinas. Ana se queda sola en el escenario, ve al público, se dirige a él, quiere decir algo, no sabe qué. Sale por un camino no convencional al escenario. Oscuro (66).

El procedimiento artístico elegido por la autora en esta última escena, la metateatralidad, forma común de la mise en abyme, consigue "desbordar" la ficción, mediante la difuminación de los límites que "lógicamente" separan la ficción de la realidad. Todos estamos expuestos... todos podríamos sufrir lo que Ana. ¿Cómo reaccionaríamos en una situación así?

Me parece que la obra plantea preguntas importantes: ¿se puede seguir mirando a otro lado; pretender que nada pasa, en tanto la violencia y la corrupción no nos afecte directamente? $\mathrm{O}$, por otro lado, ¿se le puede pedir al hombre común que se exponga, que realice acciones heroicas? La obra de Colio no da respuestas pero tampoco nos permite evadir las preguntas.

Finalmente, para cerrar estas breves reflexiones, quisiera recordar, siguiendo a Carlos García Gual, que los mitos, esos "relatos tradicionales que cuentan la actuación memorable de unos personajes extraordinarios en un tiempo prestigioso y lejano" (2011: 12), tienen también una dimensión histórica; es decir, que al volverse a contar se introducen en sus diversas versiones rasgos propios del contexto histórico en que emergen. Pero en la medida en que recrean algo que merece ser recordado, conservan su valor ejemplar pues nos hablan de la "grandeza y la fragilidad de la enigmática condición humana” (2011: 15). 


\section{Bibliografía}

Colio, Bárbara, 2010, Usted está aquí, Consejo para la Cultura y las Artes de Nuevo León, Monterrey.

Dove, Patrick, 2013, "In the Wake of Tragedy: Citation, Gesture, and Theatricality in Griselda Gambaro's Antígona furiosa", en Whose Voice is This? Iberian and Latin American Antigones, Jennifer Duprey (ed.), Hispanic Issues On Line, núm. 13, pp. $42-$ 62.

Duprey, Jennifer, 2013, "Introduction. Antigone and the Poliethical Life", en Whose Voice is This? Iberian and Latin American Antigones, Jennifer Duprey (ed.), Hispanic Issues On Line, núm. 13, pp. 1- 23.

Duroux, Rose y Stéphanie Urdician, 2012, "Cuando dialogan dos Antígonas. La tumba de Antígona de María Zambrano y Antígona furiosa de Griselda Gambaro", Olivar, núm. 17, pp. 73-96.

Gambaro, Griselda, 2003, "Antígona furiosa”, en Teatro 3, Ediciones de la Flor, Buenos Aires, pp. 195-217.

García Gual, Carlos, 2011, Mitos, viajes, héroes, FCE, Madrid.

Lasso de la Vega, José, 1989, "La presencia del mito griego en nuestro tiempo", Gerión. Revista de Historia Antigua, Anejo II, pp. 99-114.

Mogliani, Laura, 1997, "Antígona furiosa de Griselda Gambaro y su intertexto griego", en De Esquilo a Gambaro. Teatro, mito y cultura griegos y teatro argentino, Osvaldo Pellettieri (ed.), Galerna, Buenos Aires, pp. 97-107.

Nabuco, Edvaldo y Paulo Amarante, 2011, "Las 'locas' de la Plaza de Mayo", Átopos, núm. 11, pp. XX-XXVIII.

Navarro Benítez, Joaquín, 2001, "La transparencia del tiempo. Entrevista a Griselda Gambaro", Cyber Humanitatis, núm. 20. http://web.uchile.cl/publicaciones/cyber/20/entrev1.html 
Nelli, M. Florencia, 2012, “Usted está aqui: Antigone against the Standardization of Violence in Contemporary Mexico", Romance Quarterly, núm. 1, vol. 59, pp. 55-65.

Nussbaum, Martha C., 2003, La fragilidad del bien. Fortuna y ética en la tragedia y la filosofía griega, Antonio Ballesteros (trad.), Machado Libros, Madrid.

Pellarolo, Silvia. "Revisando el canon /La historia oficial: Griselda Gambaro y el heroísmo de Antígona”, Gestos, núm. 13, pp. 7985.

Popper, Karl, 2006, La miseria del historicismo, Pedro Schwartz (trad.), Alianza Editorial, Madrid.

Ricoeur, Paul, 2006, Sí mismo como otro, Siglo XXI Editores, Madrid.

Rodríguez Adrados, Francisco, 1962, "El héroe trágico", Cuadernos de la Fundación Pastor, núm. 6, pp. 11-35.

Steiner, George, 1991, Antígonas. Una poética y una filosofía de la lectura, Alberto L. Bixio (trad.), Gedisa, Barcelona.

Sófocles, 2011, “Antígona”, en Tragedias, Fernández-Galiano (introducción y versión rítmica), Austral / Planeta, Barcelona.

Tarantuviez, Susana, 2007, La escena del poder. El teatro de Griselda Gambaro, Corregidor, Buenos Aires.

Recibido: 26 de enero de 2016 Aceptado: 29 de marzo de 2016 